Marquette University

e-Publications@Marquette

College of Education Faculty Research and

Publications

Education, College of

$1-1-2012$

\title{
Toward the Prevention of Risky Sexual Behavior Among Latina Youth
}

Lisa Edwards

Marquette University, lisa.edwards@marquette.edu

Lucia J. Stubbs

Marquette University, lucia.stubbs@marquette.edu

Published version. "Toward the Prevention of Risky Sexual Behavior Among Latina Youth," in Oxford Handbook of Prevention in Counseling Psychology. Eds. Elizabeth Vera. Oxford, NY: Oxford University Press, 2012: 285-298. DOI. (C) 2012 Oxford University Press. Used with permission. 


\title{
Toward the Prevention of Risky
} Sexual Behavior Among Latina Youth

Lisa M. Edwards and Lucia J. Stubbs

\begin{abstract}
Sexual risk-taking among Latina youth has been noted as a critical health concern within the United States. In this chapter, the importance of prevention of risky sexual behavior among Latina youth will be discussed. Current prevalence rates and consequences associated with sexual behavior among Latino/as will be reviewed, along with factors that are relevant to understanding the prevention of sexual activity. Finally, programs that have been developed to prevent risky sexual behavior among Latinas will be reviewed and suggestions for prevention efforts will be presented.
\end{abstract}

Key Words: Latino/a youth, adolescent, sexual activity, prevention, teen pregnancy, risky behavior

\section{Introduction}

Adolescents today are exposed to risky behavior, such as sexual activity, at a much earlier age than in previous times (LeCroy, 2008). Youth generally begin experimenting with sexual activity during the adolescent years (LeCroy, 2008; Takanishi, 1993), and the consequences of this experimentarion can include costs to individuals' health, education, and future outcomes. For females, the added risk of pregnancy in addition to acquiring a sexually transmitted disease (STD) is problematic. Young Latinas in particular are at risk because of their early onset of sexual activity and less consistent contraceptive use (Lescano, Brown, Raffaelli, \& Lima 2009). Prevention in the area of sexual risk-taking among Latina youth is critical, as it has the porential to promote health and psychosocial wellness and help combat this significant health concern within the United States. In this chapter, we will describe the importance of prevention of risky sexual behavior among Latina youth. We will discuss current prevalence rates and consequences associated with sexual behavior among Latino/as, as well as factors that are relevant to understanding the prevention of sexual acrivity. Finally, programs that have been developed to ameliorate this health risk behavior will be revicwed and suggestions for prevention efforts will be presented. Throughout the chapter we utilize the term Latina to refer to female individuals in the United States with origins in Latin America, and consider this term inclusive of other relared terms such as Hispanic and Chicana, and national origin labels such as Mexican or Dominican.

\section{Cultural Context of Latina Adolescent Sexual Activity}

Authors have noted that adolescents, as compared to individuals in other developmental periods, are more open to experiencing and engaging in a wider range of bchaviors (Arnett, 2000). Adolescence is a critical developmental period because of youth' emerging sexualities and the fact that they are forming identities and lifetime habits at this time (Buzwell \& Rosenthal, 1996; Chapin, 2001; Michels, Kropp, Eyre, \& Halpern-Felsher, 2005). Adolescents may therefore be ar risk for poor sexual decision making because they are less 
developmentally and emotionally mature (Driscoll, Biggs, Brindis, \& Yankah, 2001).

Early sexual activity puts adolescents at risk for a variety of negative ourcomes across physical, psychological, and emorional domains (Driscoll et al., 2001; Kirby, 2007). Teens who are sexually active during early adolescence are more likely to have unprotected sex and more sexual partners, and to participate in other risk behaviors such as using drugs and alcohol and dropping out of school (Anaya, Cantwell, \& Roteram-Borus, 2003; Franzetta, Terry-Humen, Manlove, \& Ikramullah, 2006; Manlove, Logan, Moore, \& Ikramullah, 2008; Manlove, Papillio, \& Ikramullah, 2004; National Campaign to Prevent Teen Pregnancy, 2003; Silver \& Bauman, 2006). The risk of teenage pregnancy for girls, parenthood, abortion, and sexually transmitted diseases also increases with early sexual activity and may lead to significant health complications (Anaya et al., 2003; CDC, 2007a; CDC, 2008b; Vćlez-Pastrana, Gonzalez-Rodriguez, \& Borges-Hernandez, 2005; Taylor-Seehafer \& Rew, 2000). When teens give birth their future prospects decline (Centers for Disease Control and Prevention [CDC], 2007a), they are less likely to complete high school and receive prenatal care, and more likely to continue to live in poverty (Anaya et al., 2003; Hoffman, 2006). In addition, the effects of childbearing on girls may include mental illness, underperformance in school, sexual violence and abuse, family dysfunction, and poor self-esteem (Contreras, Narang, Ikhlas, \& Teichman, 2002).

Data from the 2009 YRBS (CDC, 2009) showed that in general, males and ethnic minorities were more likely to engage in risky sexual behaviors. Across ethnic groups, adolescent males are more likely than females to initiate sex at an early age and report having sex with four or more people. African American males initiate sex before 13 years of age at 6 times the rate of White males, and Latino males initiate at twice the rate compared to White males. Similarly, African American males were most likely to have four or more sexual partners, followed by Latinos and White males. With respect to condom use, Latino males and Latina youth are least likely to use condoms of all ethnic groups, followed by African Americans and Whites.

Early and high rates of sexual activity among Latina youth in particular have been identified as significant public health concerns across the United States (CDC, 2007b; Schuster, 2003). Statistics indicate that by 12 th grade, $68 \%$ of Latinas report having had sex and $22 \%$ report having had four or more sexual partners (CDC, 2009). About s; of Latinas in high school reported first intercourz before age 13 , compared to $3 \%$ of White and is of African American female students (CDC, $200 \%$ Research has noted that Latina teens are least likts to use condoms or any contraception at first sez $z$ compared to their male and female counterparts: all groups (CDC, 2006, 2009; Eaton et al., 2016; which likely often leads to the high rates of pros. nancy and sexually transmitted diseases.

With respect to sexually transmitted diseses: rates of chlamydia, gonorrhea, and syphilis are cri: and three times as high for Latinos as for Whites and Latinos accounted for $19 \%$ of new AIDS diznoses in 2006 (CDC, 2008a). Latinas also expetience disproportionately high rates of HIV infectir. In 2006, the rate of HIV infecrion in Hispari: females ages 13 to 29 was three times the rate $f i$ non-Hispanic White females (Prejean, Song, An, Hall, 2008). Latinas have the highest birthrates $\dot{x}$ all racial/ethnic groups, with rates declining over : past 15 years about half as fast as those for Whire and African American teens (Ikramullah, Schdr Manlove, \& Moore, 2007). Statistics indicate th: $51 \%$ of Latinas become pregnant at least once ty the time they are 20 years old (National Campais: to Prevent Teen Pregnancy, 2007).

Taken together, the data regarding risky sexie behavior among Latina youth suggest that ther: is a great need for prevention work in this a: Understanding factors that influence risky behaior is the first step toward prevention, and there $\mathrm{x}$. likely a multitude of complex factors that affecres: comes in this area. Some authors have speculati: that disparities across ethnic groups in age of dit: of sexual intercourse can be explained by differensi: in socioeconomic level, community, and opportnity; yet these differences don't entirely account $\bar{a}$ : the increased risk for these youth (Miller, Sage is Winward, 2005). Clearly the unique culcural cr: text of being Latina in US society also plays a n: in this puzzle.

Latina youth are expected to navigate their st ture of origin as well as mainstream, White cultr: They may experience stressors as a result of the biculturalism, including discrimination, act: turation gaps, family obligations, and pressure $\mathrm{k}$ be bilingual (Fennelly, Mulkeen, \& Giusti, I9 Flores, Tschann, Dimas, Pasch, \& deGroat, 2011 Romero, Carvajal, Volle, \& Orduńa, 2007; Rocer. \& Roberts, 2003), as well expectations about 3 der roles and pressure to conform to gender-specis: behavior (McLean Taylor, Veloria, \& Verba, $30^{\circ}$ 
Rumcro et al., 2007). Researchers have noted that any prevention efforts must incorporate and consider culture, as culture influcnces beliefs abour health including values and practices (Chwalisz \& (Obasi, 2008).

In the following section, prominent Latino/a cultural values that have been suggested to relate to sexu.l activity among youth are described. Specifically, we review relevant theory and research about the role of acculturation, familism, religiosity, and gender roles in Latina sexual risk-taking. For each value, we nute the complexity of research that has shown that the construct ac times might be protective for youth, and at other times, might serve as a risk factor.

Our goal in discussing these values is not to pathologize any aspect of culture, but rather to move the field toward a more nuanced discussion of the complexity of such constructs and how they mighr operate in the lives of Latina youth. We acknowledge that values such as these might operatc in complex ways in any ethnic group, and that within any given culture there is great heterogeneity in the level to which individuals may or may not adhere to such cultural values.

\section{Acculturation}

Acculturation has been defined as the process of change that results from continuous contact between (wo) different cultures (Berry, Trimble, \& Olnedo, 1986). Several models of acculturation have been proposed and used to guide measures of this construct. Most initial research about acculturation adopred a unidimensional approach, which situated Latino individuals, for example, on a continuum of acculturation betwecn two opposite poles of European Anerican and Latino culture. As individuals assimilated to mainstream culcure, this model suggested that they moved toward the European American and of the continuum and away from their Latino culcure. A limitation of this approach, however, was that there was no acknowledgmenc of the possibility that acculturation toward the dominant culture does not necessarily preclude the simultaneous retention of one's culrure of origin (Edwards \& Lopez, 2006; Marin, 1992; Zane \& Mak, 2003). Because acculturation is a multidimensional construct it is measured by a number of variables including: birth place, length of residency in host country, preference and fluency of language, ethnicity of friends, ethnic identity, and disposition toward family and gender roles (Driscoll er al., 2001).

It has been suggested that researchers attend ro acculturation as an important variable that can influence an individual and group's values (Berry, 2003; Chun \& Akutsu, 2003; Kim \& Abreu, 2001) and as an important factor in sexual health interventions (Lescano et al., 2009).

Research about acculturation and sexual activity has noted that youth with low levels of assimilation initiate sexual activity later than those who are more assimilated (Ford \& Nortis, 1993) and report fewer liferime sexual partners (Edwards, Fehring, Jarrett, \& Haglund, 2008). In contrast, research also exists that suggests that once sexual activity has been iniriated, being less assimilated is associated wirh decreased condom use among Latinos (Marin et al., 1993; Newcomb et al., 1998). Additionally, US-born Latinas are at a decreased risk for unplanned pregnancy than those who are immigrants (Ford \& Norris, 1993), suggesting that less assimilation is not always protective against risky sexual behavior.

More recent research has shown complexiries in the relationship berween assimilation and sexual activity, suggesting that future research will need to investigate these variables more carefully. For example, Guilamo-Ramos, Jaccard, Peña, and Goldberg (2005) found that immigrant adolescents in English-speaking homes werc at less risk for sexual activity than their counterparts in Spanishspeaking homes, while for US-born Latino youth the opposite was true.

\section{Familism}

Familism, or familismo, has been considered a core value of Latino/a culture (Marin, 1993; Sabogal, Marin, Orero-Sabogal, Marin, \& PerezSrable, 1987) and is generally defined as an individual's attachment to his/her family members and attention given to the family over him/herself. Fanilism includes strong feelings of reciprocity, loyalty, and solidarity among family members (Triandis, Marin, Betancourt, Lisansky, \& Chang, 1982). Additionally, familism refers to the feeling of closeness, getting along with, and contributing to the well-being of the family (Cauce \& DomenechRodriguez, 2002). While research with Latinos has found that aspects of familism (parental monitoring and communication) are protective against delinquency, adolescent aggression, and substance use (Barrera, Gonzales, Lopez, \& Fernandez, 2004; Formoso, Gonzalcs, \& Aiken, 2000; Gil, Wagner, \& Vega, 2000; Pabon, 1998; Ramirez, Crano, Quist, Burgoon, Alvaro, \& Grandpre, 2004; Romero \& Ruiz, 2007; Smokowski \& Bacallao, 2006), less is known about how familism may influence decisions regarding early sexual behavior. 
Some studies have noted that communication between Latino parents and their teens is related to lower incidence of pregnancy (Adolph, Ramos, Linton, \& Grimes, 1995), sexual abstinence (Aspy et al., 2009), and increased condom use (Buzi, Smith, \& Weinman, 2009). Bourdeau, Thomas, and Long (2008) note that Latino families play a role in sexual socialization because of the increased emphasis that is placed on respect for elders and parents, who are likely to emphasize the importance of virginity and delaying sexual activity until marriage. In two qualitative studies with Latino/a adolescents, the importance of respect toward family members and engaging in behaviors that bring pride to the family was related to youths' reasons for not having sex (Flores, Eyre, \& Millstein, 1998; Villarruel, 1998). In the Flores et al. study, Latinas preferred partners who had familistic orientations and whom they expected would be good providers for the family, and these values were related to more traditional sexual attitudes.

While some studies have emphasized that aspects of familism may serve as protective factors against engaging in sexual behavior among Latina youth, it also has been hypothesized that a greater emphasis on families could increase sexual risk for Latino youth, such thac youths that identify with Latino culture may feel more inclined to engage in unprotected sex or give birth if pregnancy does occur (Kirby, 2000; Miller et al., 2005). Understanding the protective role of familism, therefore, is important for prevention work in this area. More research is needed to ascertain the aspects of familism or family behaviors that are protective and those that might serve as risk factors for increased sexual activity.

\section{Religiosity}

Religiosity has been noted as an important factor related to sexual activity among Latina youth. Religiosity can be considered the degree of participation in, or adherence to, the beliefs and practices of a religion (Mueller, Plevak, \& Rummans, 2001), and religiosity has been consistently noted to hold a prominent position in Latino/a culture (Driscoll et al, 2001). A handful of studies exist that show a positive influence of religiosity on sexual activity among Latino/a youth (DuRant et al., 1990; Edwards et al., 2008; Edwards, Fehring, Haglund, \& Pruszynski, in press; Liebowirz, Castellano, \& Cuellar, 1999). In a recent study with a nationally representative data set, those Hispanic adolescents who held religion as important, attended religious services at least once a week, and had traditional attitudes on sexuality had fewer sexual partners and an older age of sexual debut (Edwards et al., 2008).

It has been noted that religiosity may be related to sexual activity and contraceptive use in different ways (Manlove, Terry-Humen, Ikramullah, \& Moore, 2006); thus it is important to study thex dependent variables separately. While religiosity is protective for delay of sexual initiation and number of partners, research is mixed about how it relates to contraceptive use. Among teens of all ethnic backgrounds, some evidence indicates that adolescents with higher religiosity report less contraceprive use than their less religious peers (Jones, Darroch, \& Singh, 2005; Nonnemaker, McNeely, \& Blum, 2006), while other studies suggest no relationship between religiosity and contraceptive use (Bearman \& Bruckner, 2001). Finally, in at least one srudy, family religiosity was a protective factor in terms of contraceptive use (Manlove et al., 2008).

For Latinas, religiosity has been suggested as a reason why they might be less likely to adhere to, or use, contraception as much as their non-Latina peers (Venkat et al., 2008). However, the relationship between religiosity and contraception use among teens, and among Latinas, is not clear. Previous stud. ies with Latino youth also have provided discrepane findings about the influence of religiosity on contraceptive use. Research with large samples of ethnically diverse adolescents (Rostosky, Wilcox, Wright, \& Randall, 2004) and Latino adolescents (Manlove et al., 2006) suggests that religious teens and those who engage in religious activities with family ane less likely to use contraception as compared to their less religious counterparts. However, other research with Latino college students (Jemmott, Jemmott, \& Villarruel, 2002), and adolescents (Villarruel, Jemmott, Jemmott, \& Ronis, 2007) found that personal religiosity was associated with an increased ust of condoms.

\section{Gender Roles}

Gender roles also have been noted to be important in shaping sexual patterns and influencing youths' sexual behavior (Deardorff et al., 2008; Taylor-Seehafer \& Rew, 2000). Gender roles have been shown to operate among Latinola youth (Marston, 2004) and lead to different expectations about sexuality among Latino boys and girls (Driscoll et al., 2001). For males, the gender role of machismo is characterized by honor, protectiveness of the family, and courage (Gloria, Ruiz, \& Castillo, 2004). The Latino female gender role, marianism: 
is based on characteristics of the Virgin Mary from Christian theology. Marianismo emphasizes that *omen should be virginal, self-sacrificing, and pure (Cauce \& Domenech-Rodrigucz, 2002; Gloria ot al., 2004) and yer also acquiescing to men's sexual desires (Peragallo, DeForge, Khoury, Rivero, \& Talashek, 2002). Paramount to this culcural value is virginity, including sancrions against engaging in premarital sex. Ac the same time, marianismo signifies a reverence of motherhood, which requires a loss of virginity (Bordeau et al., 2008; Cauce \& Domenech-Rodriguez, 2002). These opposing mesages have been proposed to contribute to the complexiry of the influence of gender roles on sexual activity for young Latinas (Liebowitz. ct al., 1999), yet little empirical research has been conducted to further elucidare these processes. In a quantitative study of Latina adolescents, Kaplan, Erickson, and Juarez-Reyes (2002) found that endorsement of traditional gender roles was related to delay of sexual activity. Similarly, a study of Latino boys and girls found that those who endorsed traditional gender roles were more likcly to report intentions to use condoms. These studies suggest that marianismo may be protective for young Latinas against risky sexual behavior, but much more work is needed in this area.

The prominent cultural values/topics that have been described (acculturation, familismo, religiosity, and gender roles) have been identified as factors that might play a role in sexual activity among Latinas. It is important to note, however, that these variables might not be unique to Latinas, and rather may represent factors that are relevant to yourh from all ethnic backgrounds. Indeed, longitudinal research has shown that as a whole, adolescents who report higher religiosity tend to delay sexual activity more than those with lower levels of religiosity (Hardy \& Raffacli, 2003). Similarly, socialization about gender role expectrations is something that all adolescents face in sociery (Denner \& Dunbar, 2004; TaylorSechafer \& Rew, 2000). And while acculturation is an experience unique to racial/ethnic minorities, ir is clearly not something that only Latinas undergo (Chun \& Akutsu, 2003). We contend, therefore, that the constructs described may be applicable to yourh from different backgrounds, but how these constructs manifest themselves will likely be very different. Addirionally, it is the confluence of multiple identities (as adolescent females of Latino background) that marks the unique experience of young Latinas, and therefore must be understood as something different.

\section{Prevention Programs for Decreasing Sexual Risk-Taking}

There are a large number of sexual healch programs aimed ar preventing negative sexual health outcomes among boys and girls of different ethnic backgrounds. Most commonly, prevention programs are designed for large groups of students or youth with considuration for developmental stagel age and gender, but with less of a focus on cultural background. Indeed, scholars have emphasized the importance of raking culture into account in sexuality interventions with Latino adolescents, yet few culcurally tailored interventions have been developed for this population (Lescano et al., 20099).

As previously stated, data shows that there are significant sexual healch differences among erhnically diverse youth (CDC, 2007a, 2007b), and Latino adolescents are parricularly affected by negative sexual health outcomes in comparison to other yourh. Given the negative well-being outcomes associated with these sexual health disparities affecting Latino/a adolescents, it is of particular imporrance to focus on the sexual programening for thesc youth.

To gain a better understanding of the prevention efforts aimed at Latina adolescents, a comprehensive search of prevention programs for risky sexual behavior was conducted. Sexual health programs were scarched using a number of research databases, including federal organizations such as the Centers for Disease Control (CDC), The National Campaign to Prevent Teen Pregnancy, and the US Census Bureau, as well as social science databases. Keywords used in this search included "Hispanic" and "Latino/a," "adolescent," "yourh" and "teenager," "sexual health/bchavior/activity," "teen pregnancy" and "prevention."

The search yielded many prevention programs, bur only those that were empirically cvaluated prevention programs for Latino/a youth were included. The specific criteria for inclusion in the search was: (1) program geared toward adolescents or youth, (2) program was empirically evaluated, and (3) program focused specifically on Latino/a youth rather than just including Latino/a youth in its sample participants. A total of 13 programs that fit these crircria were included and can be found in Table 18.1. There were only two programs located that were devcloped specifically for Latina youth, and one of these programs focused on a combination of African American females and Latina youth. The remaining programs were evaluated for both Latino boys and girls.

As can be seen in Table 18.1, a majority of the programs primarily focused on HIV/AIDS risk 
Table 18.1 Prevention Programs for Addressing Risky Sexual Behavior Among Latina/o Youth

\begin{tabular}{|c|c|c|c|c|c|}
\hline Authors & Program & Overall Purpose & Target I'opulation & Program Elements & Evaluation \\
\hline $\begin{array}{l}\text { Villarruel, Jemmott, and } \\
\text { Jemmott }(2006)\end{array}$ & $\begin{array}{l}\text { Cuidate! Take Carc } \\
\text { of Yourself: The } \\
\text { Hispanic Youth } \\
\text { Health Promorion } \\
\text { Program }\end{array}$ & $\begin{array}{l}\text { - HIV risk-reduction } \\
\text { curriculurn for Latino } \\
\text { adolescents }\end{array}$ & $\begin{array}{l}\text { - } 553 \text { adolescents } \\
\text { - } 263 \text { treatment group } \\
\text { - } 287 \text { control group }\end{array}$ & $\begin{array}{l}\text { - Aspects of Latino culture } \\
\text { - Family, gender role } \\
\text { expectations, etc. } \\
\text { - Abstinence and cundom use }\end{array}$ & $\begin{array}{l}\text { - Decreased engaging in sex } \\
\text { - Decreased having mulriple partners } \\
\text { - Decreased having unprotected sex } \\
\text { - Spanish-speakers were five times more } \\
\text { likely to have used a condom ar lasr } \\
\text { time of intercourse }\end{array}$ \\
\hline $\begin{array}{l}\text { East, Kiernan, and Chavez } \\
(2003)\end{array}$ & $\begin{array}{l}\text { Califurnia's } \\
\text { Adolescent } \\
\text { Sibling Pregnancy } \\
\text { Prevention Project }\end{array}$ & $\begin{array}{l}\text { - Teen pregnancy } \\
\text { prevcntion program } \\
\text { that emphasizes } \\
\text { abstinence and } \\
\text { contraception for the } \\
\text { adolescent siblings of } \\
\text { parenting teens }\end{array}$ & $\begin{array}{l}\text { - Elementary, middle, and } \\
\text { high school } \\
\text { - Male and female } \\
\text { - } 11-17 \text { years old }\end{array}$ & $\begin{array}{l}\text { - Delivered to siblings of } \\
\text { parenting teenagers in } \\
\text { California. } \\
\text { - Provides case management } \\
\text { and sex education }\end{array}$ & $\begin{array}{l}\text { - Dclaycd initiation of sex } \\
\text { - Decreased number of teen pregnancies }\end{array}$ \\
\hline $\begin{array}{l}\text { Walker and Kotloff }(2000) \text {; } \\
\text { Retrieved November } 17 \text {, } \\
2010 \text {, from hrtp://www. } \\
\text { Ppy.org/ppv/publications/ } \\
\text { assets/63_publication.pdf }\end{array}$ & $\begin{array}{l}\text { Hablando Claro: } \\
\text { Plain talk }\end{array}$ & $\begin{array}{l}\text { - Increase adult'teen } \\
\text { communication about } \\
\text { sex and increase sexually } \\
\text { aciive teets' access to } \\
\text { contraceptives to decrease } \\
\text { unwanted pregnancies, } \\
\text { STDs, and HIV/AIDS }\end{array}$ & $\begin{array}{l}\text { - Not specified (but this } \\
\text { adaptation of Plain Talk } \\
\text { is used primarily at sites } \\
\text { with an abundance of } \\
\text { Spanish-spcakcrs) }\end{array}$ & $\begin{array}{l}\text { "Walker and Talkers" or } \\
\text { Promuloras program: they } \\
\text { hire community residents; } \\
\text { - Residents are trained to be } \\
\text { community leaders; and } \\
\text { - Discuss sexuality and hcalth } \\
\text { parties }\end{array}$ & $\begin{array}{l}\text { - Increased communication berween } \\
\text { youth and adults and increased access } \\
\text { to contraceptives, was positively } \\
\text { correlared with teens' sexual } \\
\text { knowledge and safer sex behaviors } \\
\text { - Reduced percentage of sexually active } \\
\text { youth pregnancies from } 33 \% \text { to } 27 \%\end{array}$ \\
\hline Koniak-Griffin et al. (2008) & $\begin{array}{l}\text { HIV Prevention for } \\
\text { Latina Adolescent } \\
\text { Mothers and Their } \\
\text { Partners }\end{array}$ & $\begin{array}{l}\text { - To provide couple- } \\
\text { focused HIV/AIDS } \\
\text { prevention information }\end{array}$ & $\begin{array}{l}\text { - Latina teen morhers and } \\
\text { their male partners }\end{array}$ & $\begin{array}{l}\text { - 6-week HIVIAIDS } \\
\text { prevention curriculım }\end{array}$ & $\begin{array}{l}\text { - At } 6 \text { months chances of unprotected } \\
\text { sex is significantly reduced } \\
\text { - Condom use intentions increased for } \\
\text { participants in the experimental group }\end{array}$ \\
\hline $\begin{array}{l}\text { Jemmotr, Jemmort, } \\
\text { Braverman, \& Fong (2008) }\end{array}$ & $\begin{array}{l}\text { HIVISTD Risk } \\
\text { Reduction for } \\
\text { African American } \\
\text { and Latina Teenage } \\
\text { Women }\end{array}$ & $\begin{array}{l}\text { - Reduce HN risk } \\
\text { bchaviors among } \\
\text { female youth }\end{array}$ & $\begin{array}{l}\text { - Urban, economically } \\
\text { underprivileged fernales } \\
\text { - African American and } \\
\text { Latina adolescents }\end{array}$ & $\begin{array}{l}\text { - Clinic-based } \\
\text { - Culrurally specific } \\
\text { - Single } 4.25 \text {-hour group } \\
\text { sessions } \\
\text { - Discussions, gancs, and } \\
\text { cxpericntial activities }\end{array}$ & $\begin{array}{l}\text { - Reduced number of sex partners } \\
\text { - Reduced incidences of unprotected } \\
\text { scxual intcrcourse } \\
\text { - Long-term reduction of incidences of } \\
\text { STIs }\end{array}$ \\
\hline
\end{tabular}

Table 18.1 (Continued)

\begin{tabular}{|c|c|c|c|c|}
\hline Authors & Program & Ovcrall Purpose & Jarget J'opulation & Program Elements \\
\hline $\begin{array}{l}\text { Jemmott, Jcmmott, and } \\
\text { Fong (1998) }\end{array}$ & $\begin{array}{l}\text { Making Proud } \\
\text { Choices }\end{array}$ & $\begin{array}{l}\text { - Empowering inner-city, } \\
\text { Latino youth to use } \\
\text { condoms if they choose } \\
\text { to have sex }\end{array}$ & $\begin{array}{l}\text { - Urban, elementary, and } \\
\text { high school youth (up to } \\
24 \text { years old). }\end{array}$ & $\begin{array}{l}\text { - HIV/AIDS preventiun and } \\
\text { pregnancy prevention } \\
\text { - Abstinence is preferred but } \\
\text { contraceptive information is } \\
\text { also included } \\
\text { - Focus on goals }\end{array}$ \\
\hline
\end{tabular}

\begin{tabular}{|c|c|c|c|c|c|}
\hline $\begin{array}{l}\text { Pathways Senderos, } \\
\text { National Campaign to } \\
\text { Prevent Teen Pregnancy } \\
(2007)\end{array}$ & $\begin{array}{l}\text { Pathways } \\
\text { IScnderos }\end{array}$ & $\begin{array}{l}\text { - Create a scnse of } \\
\text { hope and future- } \\
\text { orientation for the } \\
\text { youth and emphasis } \\
\text { on responsibility and } \\
\text { academics }\end{array}$ & $\begin{array}{l}\text { - } 50 \text { youths per year } \\
-10-18 \text { years old, and } \\
\text { mostly Latino }\end{array}$ & $\begin{array}{l}\text { - (1) Education; } \\
\text { - (2) Career; and } \\
\text { - (3) Family life and sexual } \\
\text { health. }\end{array}$ & - Only 2 pregnancies in 11.5 years \\
\hline $\begin{array}{l}\text { Sellers, McGraw, and } \\
\text { McKinlay (1994) }\end{array}$ & $\begin{array}{l}\text { Poder Latino: } \\
\text { A Community } \\
\text { AIDS Prevention } \\
\text { Program }\end{array}$ & $\begin{array}{l}\text { - Prevent HIV/AIDS } \\
\text { among Latino use by } \\
\text { promoting an increased } \\
\text { use of condoms }\end{array}$ & $\begin{array}{l}\text { - Urban youth } \\
\text { - 14-20 years old }\end{array}$ & $\begin{array}{l}\text { - Media campaigns } \\
\text { - Workshops in schools } \\
\text { health centers; } \\
\text { - Educating parents and } \\
\text { community }\end{array}$ & $\begin{array}{l}\text { - Delayed sexual initiation. } \\
\text { - Male participants (not females) were } \\
92 \% \text { less likely to initiare sex. }\end{array}$ \\
\hline $\begin{array}{l}\text { Villarruel, Jemmott, and } \\
\text { Jemmotr }(2006)\end{array}$ & $\begin{array}{l}\text { Randomized } \\
\text { Controlled } \\
\text { lrial Testing an } \\
\text { HIV Prevention } \\
\text { Intervention for } \\
\text { Latino Youth }\end{array}$ & $\begin{array}{l}\text { - Validate the efficacy } \\
\text { of a prevention } \\
\text { intervention to reduce } \\
\text { sexual risk belavior } \\
\text { among Latino/a } \\
\text { adolescents. }\end{array}$ & $\begin{array}{l}\text { - } 249 \text { males and } 304 \\
\text { females } \\
\text { - } 13-18 \text { years old }\end{array}$ & $\begin{array}{l}\text { - Conducted for over } 3 \text { years } \\
\text { - Six 50-minute modules in } \\
\text { English or Spanish. }\end{array}$ & $\begin{array}{l}\text { - Reduced reports of sexual intercourse } \\
\text { - Increased consistency of condom use } \\
\text { - Syranish-speakers were more likcly to } \\
\text { have used a condom ar last intercourse }\end{array}$ \\
\hline $\begin{array}{l}\text { Kirby, Baumler, Coyle, et al. } \\
\text { (2001) }\end{array}$ & Safer Choiccs & $\begin{array}{l}\text { - Sex education program } \\
\text { for high school } \\
\text { students }\end{array}$ & $\begin{array}{l}\text { - Designed specifically for } \\
\text { I.atino/a youth }\end{array}$ & $\begin{array}{l}\text { - } 18 \text { month peer-educator } \\
\text { focused } \\
\text { - HIV workshops at } \\
\text { community settings } \\
\text { - Use of media } \\
\text { - Safe sex messages canvassing } \\
\text { in neighborhood }\end{array}$ & $\begin{array}{l}\text { - Youth were } 43 \% \text { less likely to initiate } \\
\text { sex and delayed sexual initiation } \\
\text { - Increased effective use of } \\
\text { contraceprives, IIIV testing, and } \\
\text { condom availability } \\
\text { - Reduced number of unprotected sex } \\
\text { incidences }\end{array}$ \\
\hline
\end{tabular}




\begin{tabular}{|c|c|c|c|c|c|}
\hline $\begin{array}{l}\text { Harper, Bangi, Sanchez, } \\
\text { Doll, and Pedraza (2009) }\end{array}$ & SHEROs & $\begin{array}{l}\text { - To prevent HIV infec- } \\
\text { tion among female } \\
\text { adolescents }\end{array}$ & $\begin{array}{l}\text { - Mexican American female } \\
\text { adolescents } \\
\text { - 12-21 years old }\end{array}$ & $\begin{array}{l}\text { - } 9 \text { scssions in } 3 \text { stages } \\
\text { - (1) Identifying risky sexual } \\
\text { behaviors } \\
\text { - (2) Committing to reducing } \\
\text { high risk behaviors } \\
\text { - (3) Enacting and maintain- } \\
\text { ing solutions }\end{array}$ & $\begin{array}{l}\text { - Improvements across measures of } \\
\text { condom atritudes, beliefs regarding a } \\
\text { woman's control of her sexuality } \\
\text { - Increased likelihood of carrying and } \\
\text { using condoms and abstaining from } \\
\text { vaginal sex }\end{array}$ \\
\hline de Anda (2002) & $\begin{array}{l}\text { The GIG: An } \\
\text { Innovative } \\
\text { Intervention to } \\
\text { Prevent Adolescent } \\
\text { Pregnancy } \\
\text { and Sexually } \\
\text { Transmitted } \\
\text { Infection in a } \\
\text { Latino Community }\end{array}$ & $\begin{array}{l}\text { - To prevent teen } \\
\text { pregnancy and sexually } \\
\text { transmitted infection in a } \\
\text { Latino community }\end{array}$ & - 609 adolescents & $\begin{array}{l}\text { - 6-hour intervention } \\
\text { - Pregnancy and STI } \\
\text { education }\end{array}$ & $\begin{array}{l}\text { - Increased knowledge about pregnancy } \\
\text { and STIs. }\end{array}$ \\
\hline $\begin{array}{l}\text { Retrieved from http://www. } \\
\text { wiseguysnc.org/jovenes.htm; } \\
\text { National Campaign, 2007; } \\
\text { http://www.wiseguysnc.org/ } \\
\text { jovenes.htm. Review at } \\
\text { http://www.moappp.org/ } \\
\text { Documents/curriculum_- } \\
\text { review/Files/WiseGuys.PDF }\end{array}$ & $\begin{array}{l}\text { Wise Guys/Jóvenes } \\
\text { Sabios }\end{array}$ & $\begin{array}{l}\text { - Encourages abstinence, } \\
\text { provides contracep- } \\
\text { tive information, and } \\
\text { promotes responsible } \\
\text { decision-making. }\end{array}$ & $\begin{array}{l}\text { - Latino boys } \\
\text { - 11-17 years old }\end{array}$ & $\begin{array}{l}\text { - } 10-12 \text { sessions } \\
\text { - Discuss values, future goals, } \\
\text { and sexuality. }\end{array}$ & $\begin{array}{l}\text { - Increase in parent and teen } \\
\text { communication } \\
\text { - Increase in positive attitudes toward } \\
\text { women } \\
\text { - Increased knowledge of reproduction } \\
\text { and safer sexual behavior }\end{array}$ \\
\hline
\end{tabular}


reduction (seven programs) whereas pregnancy prevention in conjuncrion with STIs prevention was a secondary emphasis (four programs). Of these programs, four explicitly stared abstinence promocion as a program goal (California's Adolescent Sibling Pregnancy Prevention Project; ¡Cuídate!; Making Proud Choices; and Wise Guys/Jovenes Sabios). However, the strong emphasis on reducing the ransmission of HIV/AIDS was particularly evident as the very names of several programs included in our evaluation used "HIV/AIDS" in their titles. Approximately $30 \%$ of the programs had names that included HIV or AIDS in the title. This indicates that the top priority of prevention efforts aimed at Latino youth seems to have been to decrease the incidences of HIV/AIDS.

Several of these programs (six) included salient aspects of Latino culture. A majoriry of these programs (four) emphasized gender roles (;Cuídate!; HIV Prevention for Latino Adolescent Morhers and Their Partners; Randomized Controlled Trial Testing and HIV Prevention Inrervention for Latino Youth; Wise Guys). Much of the work around gender roles included traditional marianismo and machismo expectations (Randomized Controlled Trial Testing; IIV Prevention Intervention for Latino Youth), masculinity, and communication (Wise Guys). Additionally, a couple of the programs emphasized parents' cultural values (Hablando Claro; HIV Prevention for Latino Adolescent Mothers and Their Partners), relationship violence (HIV Prevention for Latino Adolescene Mothers and Their Partners; Wise Guys), and immigrant status and acculturation levels (Poder Latino; Wise Guys). Religiosity was also noted as a cultural factor that was included in one of the programs (Poder Larino). Other programs integrated other significant cultural aspects including marital abstinence, carin̈o and respeto (love and respect), promotoras (peer cducators; Hablando Claro), espejo-mirroring through oral stories and refection, oppression (HIV Prevention for Latino Adolescent Mothers and Their Partners), and shared Latino identicy (Poder Latino).

Similarly, several of the programs attended to the culcurally specific needs of Latino/a youth through language. Specifically, Spanish as well as English were used in six programs:;Cuídate!; Hablando Claro; HIV Prevention for Larino Adolescent Mothers and Their Partners; Poder Latino; Randomized Controlled Trial Testing an HIV Prevention Intervention for Latino Youth; and Wise Guys. These programs accomplished this by providing bilingual services and materials/resources to the participants.
An additional shared component among a majority of these programs included increasing sexual health knowledge as a major component. Of the 13 programs, 10 explicitly stated that increasing sexual health information was a major theme in their program. Included in this were components such as reaching basic sexual information to more specific skills such as condom use and sexual negotiationrefusal techniques for future use with parners. Of these programs, nine focused on increasing condom and contraceptive knowledge.

Other programs such as Wise Guys and Hablando Claro focused on increased communication about sex between adolescents and adults. Wise Guys focused on increasing general communication between adolescents and adults, while Hablando Claro specifically focused on raising the rates of child-to-parent communicarion about sex. Ir should be noted that communication accounted for around $11 \%$ of the decrease of risky sexual behaviors in the program Hablando Claro.

Only a few programs (eight) included components that directly focused on being inclusive of Latino/a adolescents' support systems. These programs varied in their support system involvement as some were community-based and others included siblings, pecr educators, parents, male partners, and communicy members. Given the emphasis on familismo and collectivism among Latino/as, researchers have noted that family-based programs are likely to be well received (Guilamo-Ranos \& Buris, 2008; Lescano et al., 2009).

Taken together, the review of published, cvaluated prevention programs for risky sexual behavior among Latino/a youth suggests that many different types of programs exist, ranging in duration and delivery mode, as well as focus. A scarce number of sexual health programs were developed specifically for Latina youth; however, several of the programs included salient aspects of Latino culture such as gender roles, familismo, and religiosity. As can be surmised from reading this chapter, we believe that the unique cultural conrext of Latinas' lives is important to understand when studying the prevention of risky sexual behavior and when developing prevention programs. Furthermore, we acknowledge research suggesting that aligning mental health treatment and prevention interventions with clients' cultural backgrounds will yield superior outcomes (Smith, Domenech Rodriguez, $\&$ Bernal, 2011). There are many unanswered questions about the exact role of certain constructs in the prevention of sexual activity among Latina 
youth, but authors have started to assemble recommendations for how to develop effective programming for this population. Readers are directed to three publications by Advocates for Yourh: Youth of Color: At Disproportionate Risk of Negative Sexual Health Outcomes (2010), Adolescent Sexual Health and the Dynamics of Oppression: A Call for Cultural Competency (2010), and The Sexual Health of Latina Adolescents - Focus on Assets (2006), for helpful suggestions about prevention efforts with ethnic minority adolescents. Taking the recommendations from these reports and other existing research about this topic, we provide a brief lise of key issues/topics that we believe should be considered when developing prevention programs with young Latinas:

1. Development of programs based on needs assessments of Latina youth in their communities.

a. Understanding community demographics, accessibility of services, sexual health, religious and health beliefs, and other important knowledge about population.

2. Involvement of youth in designing prevention programs to ensure they are relevant, accessible, and meaningful for consumers.

a. Depending on the focus of the program, also consider including others in the lives of youthparents, cousins, uncles/aunts, friends.

3. Implementation of practices that acknowledge and respect culture.

a. Utilizing materials and communication in language of youth and families.

b. Employing staff who are commitred to cultural competence.

c. Promotion of positive Latino/a ethnic identity.

4. Exploration of gender role expectations from culture, society, family, and self.

a. Acknowledgment of the intersection of identities as female and of Latina background.

b. Discussion of orher aspects of identity such as social class, sexual orientation, religiosity, etc.

c. Acknowledgment of the influence of oppression and discrimination in the lives of young Latinas.

5. Inclusion of information about communicarion about sexual health topics.

a. Helping teens improve communication with parents, siblings, and other important extended family members. b. Considetation of Latino/a communication styles and gender role expectations.

6. Promotion of discussions about contraceptive use and contraceptive negotiation.

a. Exploration of factors that detract from anc promote use of contraceptives, particularly for Latinas.

7. Evaluation of programs for effectiveness

a. Development of an evaluation system pric: to implementation.

b. Utilization of appropriate assessments for Latino/a population.

\section{Conclusion}

Latina youth have numerous negative outcones associated with risky sexual behavior and reen pres. nancy. Given these health concerns and considezing the unique cultural context of Latina adolescens lives, researchers have begun to incorporate culcurs into prevention programs aimed ar decreasing rist? sexual behavior. To date, several programs has. been developed for Latino/a youth and have berr empirically evaluated. Their successes with variecis health outcomes are encouraging, and ic is hope: that more research in this area will be conducted the future.

\section{Future Directions}

Many questions remain that need to be addressed in order to continue to develop and implemer effective prevention of risky sexual behavior amons Latina youth. Some pressing questions to furt: the field include:

-What is the influence of marianismo and machismo on sexual risk-taking (initiation of sexus activity and contraceptive use) among Latina youth?

- How do Larina youth negotiate sexual encounters and make decisions regarding sexual activity?

- What are the most effective aspects of prevention programs for decreasing risky sexual behavior among Latina/o youth?

- How effective are programs that directly address aspects of young Lacinas' cultural context in comparison to those that are more general?

\section{References}

Adolph, C., Ramos, D. E., Linton, K. L. P., \& Grimes, D. L. (1995). Pregnancy among Hispanic teenagers: Is good parttal communication a deterrent? Contraception, 51, 303-3it. 
Adrocates for Youth (2006). The Sexual ITealth of Latima Adolescents-Focus on Assets. Washingron, DC.

Advacates for Youth (2010). Adolescent Sexual Heallh and the Dynamics of Oppression: A Call for Culsural Competency. Washington, DC.

Atvocates for Youch (2010). Youth of color: At disproportionute risk of negative sexual bealth outcomes. Washington, $\mathrm{DC}$.

Anaya, H. D., Cancwell, S. M., \& Roreram-Borus, M. J. (2003). Sexual risk behaviors among adolescents. In A. Biglan, M. C. Wang, \& H. J. Walberg (Eds.), Preventing youth problems (pp. 113-143). New York: Kluwer Academic/Plenum.

trnett, J. J. (2000). Emerging adulthood: A theory of development from the late reens through the twenties. Americun Psychologist, 55, 469-480.

Aspy, C. B., Vesely, S. K., Tolma, E. L., Oman, R. F., Fluhr, J., Rodine, S., \& Marshall, L. (2009). Youth assers and delayed coitarche across developmental age groups. Journal of Eurly Adolescence, 30(2), 277-304.

Harrera, M., Jr., Gonzales, N. A., Lopez, V., \& Fernandez, A. C. (2004). Problen behaviors of Chicana/o and Latina/o adolescents: An analysis of prevalence, risk, and protective facrors. In R. J. Velasquez, L. M. Arclliuto, \& B. W. McNeil (Eds.), The loandbook of Chicanulo psychology and mental heulth. Mahwah, $\mathrm{NJ}$ : Erlbaum.

Bcarman, P., \& Bruckner, H. (2001). Promising the future: Virginity pledges and first intercourse. American fourmal of Suciologk 106, 859-912.

Burry, J. W. (2003). Conceptual approaches to acculturation. In K. M. Chun, P. B. Organisra, \& G. Marin (Eds.), Acculturation: Advances in theory, measurement, and applied researcls (pp. 17-37). Washingron, DC: American ['sychological Association.

Berry, J. W., Trimble, J. E., \& Olmedo, E. L. (1986). Assessment of acculturation. In W. J. Lonner \& J. W. Berry (Eds.), Field meshods in cross-cultural research (pp. 291-345). Beverly Hills, CA: Sage.

Bourdeau, B., Thomas, V. K., \& Long, J. K. (2008). Latino sexual styles: Developing a nuanced understanding of risk. Journal of Sex Research, 45, 71-81.

Buzi, R. S., Smith, P. B., \& Weinman, M. L. (2009). Parental communication as a protective factor in increasing condom use among minority adolescents. International journal of Adolescent Medical Health, 21, 51-59.

Buzwell, S., \& Rosenthal, D. (1996). Constructing a sexual self: Adolescents' sexual self-perceptions and sexual risk-taking. Journal of Researcls on Adolescence, 6, 489-513.

Carvajal, S., Volle, F., \& Orduña, M. (2007). Adolescenr bicu!tural stress and its impact on mental well-being among Latinos, Asian Americans, and European Americans. Jourrul of Community Psychology 35, 519-534.

Cauce, A., \& Domenech-Rodriguez, M. (2002). Latina/o families: Myths and realities. In J. M. Contreras, K. A. Kerns, \& A Neal-Barnett (Eds.), Latinalo children and families in the United States: Current research and future directions (pp. 3-25). Westporr, CT: Pracger.

Centers for Disease Control and Prevention (CDC). (2006, June 9). Youth Risk Bchavior Surveillance--United States, 2005. Surveillance Summaries. Morbidity and Mortality Weekly Repart, 55(No. SS-5).

Centers for Disease Control and Prevention. (2007a). Trends in the prevalente of sexual behavion, National Youth Risk Betuavior Survey: 1991-2007. Retrieved January 3, 2009, from hetp:// www.brhpc.org/files/yrbs07_us_sexual_behaviors_trend.pdf .
Centers for Disease Control and Prevention. (2007b). 2007 Youth Risk Behutuior Survey. Retrieved January 3, 2009, from www.cde.gov/yrbss

Centers for Disease Control and Prevention. (2008a). HIV/ AIDS among Hispanics/Latinos. Rerrieved January 3, 2009, from http://www.cdi.gov/hiv/hispanics/resources/factshects/ hispanic.hem.

Centers for Disease Control and Prevention. (2008b). Irevention challenges. Retrieved January 3, 2009, from http://www.cdc. gov/hiv/hispanics/challenges.hem

Centers for Distase Control and Prevention. (2009). YRBSS Youth unline: Comprelsensive results 2009. Accessed March 15, 2010, from hetp://apps.nced.cdc.gov/yrbss/.

Chapin, J. (2001). It wont happen to me: The role of optimistic bias in African American ceens' risky sexual practices. The Iloward Journal of Communications, 12, 49-59.

Chun, K. M., \& Akutsu, P. D. (2003). Acculturation among ethnic minority families. In K. M. Chun, P. B. Organista, \& G. Marin (Eds.), Acculturution: Advances in theory, measurement and applied research (pp. 95-119). Washington, DC: American P'sychological Association.

Chwalisa, K., \& Obasi, E. (2008). Promoting healch and preventing and reducing disease. In S. Brown \& R. Lenc (Eds.), Ilundbook of counseling psychology (4th ed.). New York: Wiley.

Contreras, J. M., Narang, D., Ikhlas, M., \& Teichman, J. (2002). A conceptual model of the determinants of parenting among Latina adolescent mothers. In J. Contreras, K. Kerns, \& A. Neal-Barnet (Eds.), Latino children and families in the United Sittes: Current reseurch and future directions (pp.155-177). Westport, CT: Praeger.

de Anda, D. (2002). The GIG: An innovative intervention to prevent adolescent pregnancy and sexually transmitted infection in a Latino community. Journal of Ethric and Cultural Diversity in Social Work, 11, 251-277.

Deardorff, J., Tschann, J. M., \& Flores, E. (2008). Sexual values among Latina/o yourh: Measurement development using a culturally based approach. Cultural Diversity and Ethnic Minority Psychology, 14, 138-146.

Denner, J., \& Dunbar, N. (2004). Negotiating femininity: Power and strategies of Mexican American girls. Sex Roles, 50(5-6), 301-314.

Driscoll, A. K., Biggs, M. A., Brindis, C. D., \& Yankah, E. (2001). Adolescent Latino reproductive health: A review of the literature. Hispanic Journul of Belsavioral Sciences, 23, 255-326.

DuRant, R. H., Pendergrast, R., \& Scymore, C. (1990). Sexual behavior among Hispanic female adolescents in the United States. Pediutrics, 85, 1051-1058.

East, P., Kiernan, E., \& Chavez, G. (2003). An evaluation of California's adolescent sibling pregnancy prevention program. Perspectives on Sexual and Reproductive Health, 35 , $62-70$.

Eaton, D., Kann, L., Kinchen, S., Ross, J., Hawkins, J., Harris, W., et al. (2006).Yourh risk behavior surveillance-United States, 2005. Morbidity and Mortality Weekly Report, 55 (No. SS-5).

Edwards, L. M., Fehring, R., Haglund, K., \& Pruszynski, J. (2011). Religiosity and sexual risk behaviors among Latina adolescenes: Trends from 1995-2008. Journal of Women's Health, 20, 871-877.

F.dwards, L. M., Fehring, R., Jarrett, K., \& Haglund, K. (2008). The influence of religiosity, gender, and language preference 
acculturation on sexual activity among Latino/ 3 adolescents. Hispanic Journal of Behavioral Sciences, 30, 447-462.

Edwards, L. M., \& Lopez, S. J. (2006). Perceived family support, acculturation, and life satisfaction in Mexican American youth: A mixed methods exploration. Journal of Counseling Psychology 53, 279-287.

Fennelly, K., Mulkeen, P., \& Giusti, C. (1998). Coping with racism and discrimination: The experience of young Lacino adolescents. In H. I. McCubbin, E. A. Thompson, A. I. Thompson, \& J. E. Fromer (Eds.), Resiliency in Native American and immigrant families (pp. 367-383). Thousand Oaks, CA: Sage.

Flores, E., Eyre, S. L., \& Millstein, S. G. (1998). Sociocultural beliefs related to sex among Mexican American adolescents. Hispanic Journal of Behavioral Sciences, 20, 60-82.

Flores, E., Tschann, J. M., Dimas, J. M., Pasch, L. A., \& deGroar, C. L. (2010). Perceived racial/ethnic discrimination, posttraumatic stress symptoms, and health risk behaviors among Mexican American adolescents. Journal of Counseling Psychology, 57, 264-273.

Ford, K., \& Norris, A. E. (1993). Urban Hispanic adolescents and young adults: Relationship of acculturation to sexual behavior. Jourmal of Sex Research, 30, 316-323.

Formoso, D., Gonzales, N. A., \& Aiken, L. S. (2000). Family conflict and children's internalizing and externalizing behavior: Protective factors. American Journal of Community Psychology 28, 175-199.

Franzetta, K., Terry-Humen, E., Manlove, J., \& Ikramullah, E. (2006). Trends and recent estimates: Contraceptive use among U.S. teens. Washington, DC: Child Trends Research Brief.

Gil, A., Wagner, E., \& Vega, W. (2000). Acculturation, farnilism, and alcohol use among Latino adolescent males: Longitudinal relations. Journal of Comimunity Psychology, 28, 443-458.

Gloria, A. M., Ruiz, E. L., \& Castillo, E. M. (2004). Counseling and psychotherapy with Latino and Latina clients. In T. B. Smith (Ed.), Pratticing multiculturulism: A/fhrming diversity in counsting and psychology (pp. 167-189). Boston: Pearson Education.

Guilamo-Ramos, V., \& Buris, A. (2008). Parent-adolescemt communication about sex in Latino families: $A$ guide for practitioners, The National Campaign to Prevent Teen and Unplanned Pregnancy. Retrieved November 10, 2010, from http://www.thenationalcampaign.org/resources/pdf/pubs/ Parent_AdolFINAL.pdf

Guilamo-Ramos, V., Jaccard, J., Peńa, J., \& Goldberg, V. (2005). Acculcuration-related variables, sexual initiation, and subsequent sexual behavior among Puerto Rican, Mexican, and Cuban youth. Health Psychology 24, 88-95.

Hardy, S. A., \& Raffaclli. (2003). Adolescent religiosity and sexuality: An investigation of reciprocal influences. Journal of Adolescence, 26, 731-739.

Harper, G. W., Bangi, A. K., Sánchez, B., Doll, M., \& Pedraza, A. (2009). A quasi-experimental evaluation of a community-based HIV intervention for Mexican American female adolescents: The SHERO's program. AIDS Education and Prevention, 21, 109-123.

Hoffman, S. D. (2006). By the numbers: The public costs of adolescent childbearing. Washington, DC: The National Campaign to Prevent Teen Pregnancy.

Ikramullah, E., Schelar, E., Manlove, J., \& Moore, K. A. (2007). Fucts at a glance: $A$ fact sheet reporting national, state-level, and city-level trends in teen childbearing. Washington, DC: Child Trends.
Jemmott, J. B., III, Jemmott, L. S., \& Fong, G. T. (19\%8. Abstinence and safer sex HIV risk-reduction intervenitic for African American adolescents: A randomized contrids trial. Journal of the American Medical Association, 27\%, 152, 1536.Jemmotr, J. B., Jennmott, L. S., Braverman, P. K. is Fong, G. T. (2005). HIV/STD risk reduction intervencis! for African American and Latino adolescent girls at an ids. lescent medicine clinic. Archives of Pediatrics od Adsicion Medicine, 159, 440-449.

Jemmott, L. S., Jemmott, J. B., III, \& Villarruel, A. (2005). Predicting intentions and condom use among latino colles: students. Journal of the Association of Nurses in AIDSCas 13(2), 59-69.

Jones, R., Darroch, J., \& Singh, S. (2005). Religious diffs. entials in the sexual and reproducrive behaviors of pous? women in the United States. Journal of Adolescent Hedilh $30^{\circ}$ 279-288.

Kaplan, C. P., Erickson, P. 1., \& Juarez-Reyes, M. (2019?] Acculturation, gender role orientation, and reproductirs risk-taking behavior among Latina adolescent family pirt. ning clients. Journal of Adolescent Research, 17, 103-121.

Kim, B. S. K., \& Abreu, J. M. (2001). Acculturation measur: ment. In J. G. Ponterotto, J. M. Casas, L. A Suzuki, \& C M. Alexander (Eds.), Handbook of multicultural coundings (pp. 394-424). Thousand Oaks, CA: Sage.

Kirby, D. (2000). School-based interventions to prevent tanpotected sex and HIV among adolescents. In J. Peterson, \& R R DiClemente (Eds.), Handbook of HIV prevention. New Yeri Kluwer Academic/Plenum.

Kirby, D. (2007). Emerging answers 2007: Research findings st programs to reduce seen pregnancy and sexually transmitsed dit: eases. Washington, DC: The National Campaign to Presn: Teen and Unplanned Pregnancy.

Kirby, D. B., Baumler, E., Coyle, K. K., Basen-Engquist K. Parcel, G. S., Harris, R., \& Banspach, S. W. (2004). The "Safer Choices" intervention: Its impact on the sexual bets: iors of different subgroups of high school students. Jownstif Adolescent Health, 35, 442-452.

Koniak-Griffin, D., Lesser, J., Henneman, T., Huang, R, Huars. X., Tello, J.,...Cumberland, W., G. (2008). HIV prevenksa for Latino adolescent mothers and their partness. Werst Journal of Nursing Research, 30, 724-742.

LeCroy, C. W. (2008). Intervention with adolescents. I K. M. Sowers, W. Rowe, \& L. A. Rapp-Paglicci (Eds, Comprehensive handbook of social work and social weiffar lo? 288-309). Hoboken, NJ: Wiley.

Lescano, C. M., Brown, L. K., Raffaelli, M., \& Lima, L. $\{20(s)\}$ Cultural factors and family-based HIV prevention interent. tion for Latino youth. Journal of Pediatric Poychologs 3 it. 1041-1052.

Liebowitz, S. W., Castellano, D. C., \& Cuellar, I. (1942). Factors that predict sexual behavior among young Mexia: American adolescents: An exploratory study. Hispunic Journis' of Behavioral Sciences, 21, 470-479.

Manlove, J., Logan, C.; Moore, K. A., \& Ikramullah, E. (29mit. Pathways from family religiosiry to adolescent sexual acjist and contraceptive use. Perspectives on Sexual and Reprodwitit Health, 40, 105-117.

Manlove, J., Papillio, A. R., \& Ikramullah, E. (2004). Nor k. Programs to delay first sex among teens. Washington, $D C$ National Campaign to Prevent Teen Pregnancy.

Manlove, J. S., Terry-Humen, E., Ikramullah, E. N., \& Moore K. A. (2006). The role of parent religiosity in teen's transitions
Narin, 1

amo

ing $c$

Psyc

Jarin, 1

self-

P. K

SUT

Marin,

M.

atris

แมn

175

Marstol

peo

nor

Silitas

girl

\& I

$21 \varepsilon$

Nithel

B.

adc

kns

diller,

pre

on

ith

Sp1

Viutle

inv

dit

Natior

sex

ibe

hts

Satior

sidj

gra

bt

SS

Kowa

WW

(1

pr

43

Vinn

PI

Sn

31

Pabor.

ilj

9

lerag;

T:

C

$C$

Preje:

es

L 
to sex and contraceprion. Journal of Adolescent Health, 39, 578-587.

Narit, G. (1992). Issues in the measurement of acculturation among Hispanics. In K. F. Geisinger (Ed.), Psychological testing of Hispanits (pp. 235-251). Washington, DC: American Psychological Association.

. Warin, G. (1993). Influence of acculturation on familialism and self-identification among Hispanics. In M. E. Bernal \& G. P. Knight (Eds.), Etbnic identity (pp. 181-196). New York: SUNY Press.

Marin, B. V., Tschann, J. M., Gomez, C. A., \& Kegcles, S. M. (1993). Acculturation and gender differences in sexual actioudes and behaviors: Hispanic vs. non-Hispanic White usmarried adults. American Journal of Public Healtl, 8.3, $1752-1761$.

Marston, C. (2004). Gendered communication among young prople in Mexico: Implications for sexual health interventions. Social Science and Medicine, 59, 445--456.

JicLan Taylor, J., Veloria, C. N., \& Verba, M. C. (2007). Larina girls: We're like sisters-most rimes! In B. J. Ross leadbeater \& N. Way (Eds.), Urban girls revisited building strengths (pp. 218-243). New York: New York University P'ress.

Michels, T. M., Kropp, R. Y., Eyre, S. L., \& Halpern-Felster, B. L. (2005). Initiating sexual experiences: How do young adolescents make decisions regarding early sexual activiry? funrul of Research on Adolescence, 15, 583-607.

Miller, B. C., Sage, R., \& Winward, B. W. (2005). Adolescent pregnancy. In T. P. Gullotta \& G. R. Adams (F.ds.), Ilandlook on the treatment and prevention of dysfunctional belsuvior: Theary practice and prevention (pp. 567-587). New York: Springer.

Mueller, P. S., Plevak, D. J., \& Rummans, T. A. (2001). Religious involvement, spirituality, and medicine: Implicacions for dinical practice. Mayo Chinic Proceedings, 76, 1225-1235.

National Campaign to Prevent Teen Pregnancy. (2003). Teen sexual activity, pregrancy, and childbearing among Latinalus in the United States: Fuct Sheet. Retrieved June 10, 2008, from htep:/www.thenationaliampaign.org

National Campaign to Prevent Teen Pregnancy. (2007). Science says: Effective and promising teen pregnancy prevention programs for Latino youth. Retrieved November 30, 2010, from http://www.thenationalcampaign.org/resources/puff/SS/ SS43_TPPProgransLatinos.pdf

Nwoumb, M. D., Wyat, G. E., Romero, G. J., Tucker, M. B., Wayment, H. A., Carmona, J. V.,... Mitchell-Kernan, C. (1998). Acculturation, sexual risk taking, and HIV bealih promotion among Latinas. Journal of Counseling Isychology, 45, 454-467.

Nonnemaker, J. M., McNeely, C. A., \& Blum, R. W. (2006) Public and private domains of religiosity and adolescent smoking transitions. Social Science and Medicine, 62, $3084-3095$.

Pabon, E. (1998). Hispanic adolescent delinquency and the family: A discussion of sociocultural influences. Adolescence, 33, $941-955$.

leragallo, N., DeForge, B. R., Khoury, Z., Rivero, R., \& Talashek, M. (2002). Latinas' perspectives on HIV/AIDS: Cultural issues to consider in prevention. Hispanic Heulth Care International, 1, 11-23.

Prejean, J., Song, R., An, Q., \& Hall, H. (2008). Subpopulation estimates from the HIV incidence surveillance system United Seates, 2006. Morbidity and Mortality Weekly Report, 57(36). 985-989.
Ramirez, J. R., Crano, W. D., Quist, R., Burgoon, M., Alvaro, E. M., \& Grandpre, J. (2004). Acculturation, familism, parental monicoring, and knowledge as predictors of marijuama and inhalant use in adolescents. Byychology of Addictive Belutvion, 18. 3-11.

Romero, A. J., \& Roberts, R. E. (2003). Stress within a bicultural context for adolescents of Mexican descent. Culturul Diversity and Et/mic Minority Psychologx, 2, 171-184.

Romero, A. J., \& Ruiz, M. (2007). Does familism lead to increased parental monitoring?: Protecrive factors for coping with risky belavious. Joumul of Child and Fumily Siudies, 16. 143-154.

Rostosky, S., Wilcox, B., Wright M., \& Randall, B. (2004). The impact of religiosity on adolescent sexual behavior: A review of the evidence. Journat of Adolescent Reseurch, 19. 677-697.

Sabogal, F., Marin, G., Otero-Sabogal, R., Marin, B. V., \& Perez-Srable, E. J. (1987). Hispanic familism and acculturation: What changes and what doesn't? Hispanic Journal of Belational Sriences, 9, 397-412.

Schuster, C. (2003, Scptenber). Latina adolescent health. Issues at a Glance. www.advocatesforyouth.org

Setlers, D. E., McGraw, S. A., \& McKinlay, J. B. (1994). Does the promotion and discribution of condoms increase sexual activity? Evidence from an HIV prevention program for Larino youth. American Journal of Public Mealth, 84, 1952-1959.

Silver, E. J., \& Bauman, I.. J. (2006). The association of sexual experience with attitudes, belicfs, and risk behaviors of inner-ciry adolescunts. Journal of Ressurch on Adolescence, 16, $29-45$.

Smich, T. B., Domenech Rodriguez, M., \& Bernal, G. (2011). Culture. Joumal of Clinical Psychology: In Session. 67, 166-175.

Smokowski, l. R., \& Bacallao, M. I.. (2006). Acculturation and aggression in Latina/o adolescents: $A$ structural model focusing on culcural risk factors and assets. Journal of Abmormal Child Psychology 3f, 657-671.

Takanishi, R. (1993). The opportunities of adolescenceresearch, interventions, and policy: Introduction to special issuc. American Pychologist, 48, 85-87.

laylor-Sechafer, M., \& Rew, L. (2000). Risky sexual bchavior among atolescent women. Jourual of the Society of Pediatric Nurses, 5, 15-25.

Triandis, H. C., Marin, G., Betancourt, H. I.sansky, J., \& Chang, 6 , (1982). Dimensions of familism anong Hispanic and mainstretm Navy recruits. Technical report No. 14. Champaign: Department of Psychology, University of Illinois, Champaign.

Vélez-Pastrana, M. C., Gonzalez-Rodriguez, R. A., \& BorgesHernandez, A. (2005). Fomily functioning and early onset of sexual intercourse in Latino adolescents. Adolesicence, 40, 777-791.

Venkat, l., Masch, R., Ng, E., Cremer, M., Richman, S., \& Arslan, A. (2008). Knowledge and beliefs abour contraception in usban Latina women. Journal of Community Heallh, 3, 357-362.

Villarruel, A. M. (1998). Cultural influences on the sexual attitudes, beliefs, and norms of young Latina adolcscents. Joumul of the Society of Pediatric Nurses, 3, 69-79.

Villarruel, A. M., Jemmott, J. B., \& Jemmott, L. S. (2006). A randomized controlled rrial testing an HIV prevention intervention for Latino youth. Arthines of Pediatric and Adolescent Medicine, 160, 772-777. 
Villarruel, A. M., Jemmotr, III, J. B., Jemmott, L. S., \& Ronis, D. L. (2007). Predicting condom use among sexually experienced Latino adolescents. Western Journal of Nursing Research, 29, 724-738.

Walker, K. E., \& Kotloff, L. J. (2000). Plain Talk: Addressing adolescent sexuality through a community initiative. Philadelphia, PA: Public/Private Ventures.
Zane, N., \& Mak, W. (2003). Major approaches to the measurment of acculturation amongethnic minority populariors.! content analysis and an alternative empirical strategy: in $\mathrm{K}$ M. Chun, P. B. Organista, \& G. Marin (Eds.), AcculfuntissAdvances in theory, measurement, and applied resurat (pp. 39-60). Washington, DC: American Psycholazia' Association. 